\title{
EDOARDO GELLNER AND \\ THE VILLAGE OF CORTE DI CADORE
}

\author{
A
}

This paper views to describe the Villaggio Eni, located in Borca di Cadore and designed by Edoardo Gellner in the 50's, as one of the most important examples of mountain architecture, and a unique case study about concurrent designing of the buildings especially the Colony - and the community hosted in them, from the master plan to details.

The Children camp is considered a summary of the architect's entire work. Many ideas about the use of wood, stone - materials belonging to the local traditional technique of construction - and cast-in-place or precast concrete are carried out in the children's camp. In particular, different concrete formworks were used to obtain different patterns and textures. and the use of modular precast concrete led to multi-scale shapes and numerous combination options. These solutions aimed at blending in of the artificial elements with nature into an unspoilt environment.

Starting from these premises, the aim is to analyse the planning, technical and formal decisions made in the Children camp in relation to the post Second World-War debates on prefabrication - especially regarding the INA-CASA house building - and the new language for alpine architecture. 


\section{METHODOLOGICAL APPROACH}

This research starts from the rich documentation of the Fondo Edoardo Gellner, conserved at the IUAV University Project Archive, and in particular of the material concerning Villaggio Eni, based in Borca di Cadore, which was decided to be analysed as a whole, from a wider perspective through the tables containing the general plans of the system up to the scale of the "executive" detail. In this regard, it seems useful to point out how the large amount of material stored in the IUAV Projects Archive strongly influenced the methodological approach to this research, which had to take into account a sort of "intrusiveness" of Gellner himself, who, in his last years, devoted himself to the reorganisation of his archive, sometimes arriving at reinterpretations $a$ posteriori. Alongside this documentation closely related to the design of the Village, it has proved to be very useful to study the correspondence between Gellner and the newspapers of the time, his interpretations and, last but not least, his expectations regarding his work at Borca di Cadore. The documents held at the IUAV University are not, however, the only sources for a work about this author that is minimally exhaustive: the fund left by Gellner himself to the Angelini Foundation of Belluno has therefore constituted an indispensable complement of the body of documentation, although we must cope with a significant discrepancy between the catalogue of works of the Gellner legacy and those actually available. Nevertheless, the latter were undoubtedly useful in tracing some of the publications read by the architect, indispensable to better identify what he looked at and what his "literary" references were.

It should be noted that the project of Corte di Cadore - so renamed by Mattei himself in memory of the historic Agip of Cortemaggiore - is located in a particularly fruitful period for Italian architecture, within which it is unique. The Eni Village, in fact, despite being a temporary holiday area, meant for the summer mountain stay of Eni employees, following the line dictated and strongly supported by Enrico Mattei, immediately adopted a series of characteristics typical of residential neighbourhoods, and yet deviating significantly from the large study carried out in those years mostly by INA-CASA. It is this peculiarity that makes the Village of Borca a reference case in the Italy of the 1950s, catching the attention of the architects of the time also outside the national borders, and justifying today the interest of the scholars concerning not only the technical and constructive aspects, but above all the design philosophy underlying them and the social implications. The attention for the community that was supposed to inhabit the Village was always a firm point in Gellner's reflection, who devoted great care to the creation of spaces capable to positively affect the relationship between the people and the inhabited places, as well as both of these, on a very 
large scale, with the urban planning of the whole village, and on the smaller and more particular one of the Colony, where it is architecture - in the interior distribution of the spaces, in the choice of materials, in the design of internal routes - to put itself at the service of individuals.

\section{THE VILLAGGIO ENI OF CORTE DI CADORE}

The idea of the village of Borca di Cadore originated around 1954 from the strong impulse of Enrico Mattei, the president of the public group, whose choice fell on Edoardo Gellner, who was working for Agip at the design of a motel in Cortina. The aim of the public company was to create an array of houses that could accommodate Eni employees with their families, equipping the complex with some common services and a summer camp for children, to be used during the vacation period. Since this project was particularly dear to the top management, in the preliminary phase, the client and the designer analysed and discussed in detail not only the area where the complex and its urbanistic design would have arisen, but also the aspects relating to the general organisation of the Village and to his managerial features. A complex and articulated design genesis thus originated, also influenced by the relationship, not always easy, with the local communities: if, at the beginning, the Village had been imagined as a system of dwellings to be built near the inhabited centre, with which it would have shared public facilities and services, when the population opposed, they opted for the creation of a more complex plant, beginning to outline the final conformation as a real self-sufficient organism, which only interacted with Borca for issues related to the means of communication: the railway and the Alemagna road. Since $1956^{1}$, coinciding with the expansion of the Village and the acquisition of lands from the neighbouring municipality of Vodo, Gellner

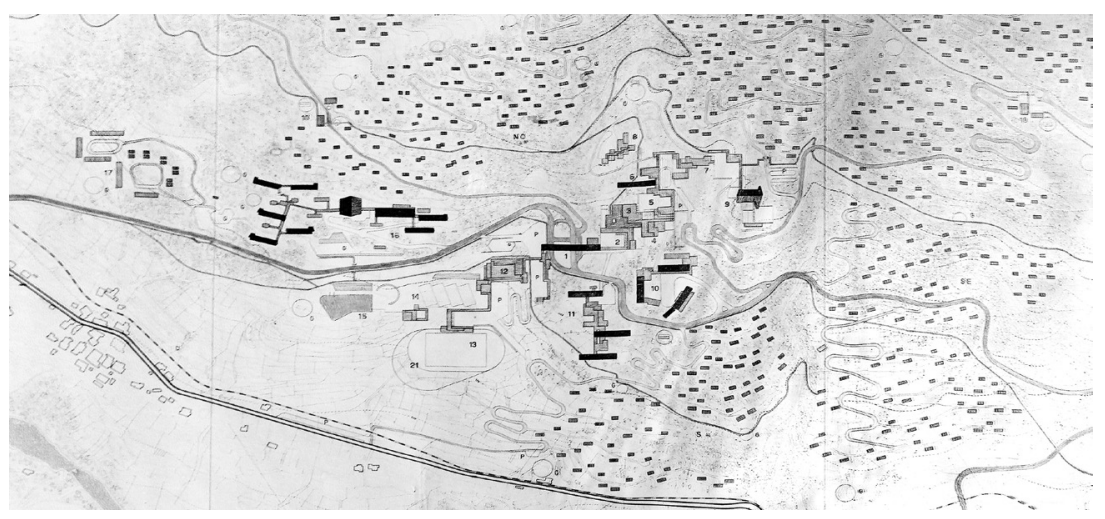

Figure 1. Urban design (AP IUAV, Gellner, Dis Ur, 26 06.11.1959 - Scatola 34) 
dedicated himself to the study of road links to the town, in an attempt to improve the connection between the complex and the city centre through the design of a direct access with the aim of "maximising traffic flow through a minimum of intersections" with particular attention to the pedestrian paths, designed so as to be independent from the main route and have a track as straight as possible ${ }^{3}$. Inside the archive, there is a rich series of design sketches showing how the designer studied the most appropriate road system solution and considered road junctions, accesses to secondary roads, giving the vivid impression of wanting to create a fluid, flowing system, within which one can move freely; Reflections that demonstrate the full awareness of the ability of the road layout to highlight the areas they cross, including the private land that would have been crossed by the new connection between the village and the town centre ${ }^{4}$. In this regard, we know about the clash with Enrico Mattei on the role of cars inside the Village; although the client was initially willing to exclude them from the complex, fearing that they could highlight social differences between the employees generating conflict, Gellner insisted instead on the opportunity to pay particular attention to private transport, proposing to provide a garage inside the houses and setting the design around the road systems, which meander through the different buildings and regulate the functional hierarchies of the whole complex. A variant of the project in $\mathrm{Nedui}^{5}$, in which Gellner had placed the village at first ${ }^{6}$, shows that some of the distributive features that will be placed in the definitive urban system were already clear in the mind of the designer: a series of houses arranged mainly into groups of three connected by main and secondary road systems, and two denser, undefined conglomerates, most likely identifiable with the Colony and the Civic Centre. The definitive location in the Borca municipality ${ }^{7}$, elaborated starting from 1954, coincided instead with the more precise definition of the different areas that will define the Village: the houses, the two hotels, the Church, the Colony and the Civic Centre. The latter, true poles of the entire composition, from simple rectangular bars are transformed, in the succession of the versions of the drawings, into systems composed of polygonal pavilions arranged so as to form compact agglomerations without particular hierarchies between the different buildings, eventually evolving into a more defined system of pavilions, distinguished by different types and shapes, and in a more "open" and disintegrated complex, where individual buildings are isolated and seem to be referable back to the final functional division.

The evolution of the Colony continued in the following years with progressive adaptations: in 1956, the hexagonal pavilion of the reception appeared (an analogous one was also inserted in the Campsite), the Colony assumed its definitive conformation ${ }^{8}$, while the Civic Centre, composed of a series of buildings spaced apart and connected by ramps, acquired a circular disposition 
more closed for the outside 9 . In December ${ }^{10}$, the projects show a Camp moved westward and the expansion of Vodo, while the Village is expanding, progressively becoming more complex and articulated, highlighting Gellner's attempt to unify this complex system through the use of a common language, consisting of buildings in line, hexagonal pavilions and connecting elements. Over the next two years the central problem for Gellner was represented by the Civic Centre, which, however, will not find an urban scale definition until the end of 1958, and on which basis the Corte di Cadore hotel was designed, and the Church rotated.

The number of drawings and sketches related to the urbanistic planning is, on the Gellner maps, quite small; nevertheless, they allow us to detect how Gellner first studied the heliothermal orientation that might be the most effective, and, later on, set the different agglomerations. There is also a considerable difference between the detail of his planimetric organisation of the Colony and that of the Civic Centre; it is also possible to see how Gellner works on the projects of the colony and of the houses on different scales at the same time, thus managing both the urban and the very architectural level, obtaining a greater definition of the general system.

An increasingly complex system begins to take shape, within which Gellner studies and conceives new functions, integrating those elements planned from the start - Colony, houses with collateral services, hotels and a civic centre whose church was to represent the culmination - with others, whose functions are not necessarily crucial in a tourist village, but which seem to make the Borca complex look like the centre of a real independent community ${ }^{11}$. The architect's notes thus begin to appear in crafts such as shops of tailoring, shoemaking, knitwear with machine room, or even barber, hairdresser, perfumery, florist, even imagining goldsmith shops, jewelleries and clockmakers, accompanied by some thoughts, then merged into a series of reports presenting the Village and regarding the range of services to be offered to its inhabitants. In particular, Gellner's reflections concentrate on the Civic Centre, whose functional aspects' importance should prevail on the psychological one, with the consequent need to create a natural system as natural as possible ${ }^{12}$. The possibility of opening the Village's services to external users is also taken into consideration, so as to make it attractive to the surrounding areas and avoiding the risk of turning it into a "lifeless body, or at most, a dormitory"'. Indeed, in some notes later, Gellner comes to hypothesise the addition of educational functions, imagining the realisation - never happened - of a school based on the Montessori Method. Providing insights on the architectures of the Village, two issues about the architect's and customer's intentions, addressed in heated debates during the 
postwar period, are solved: the need to adopt a new mountain language and prefabrication system as a response of a quick construction. The refusal to use forms and styles tied to local folklore stems from the will to create an authentic and modern mountain architecture, which can interact with its surroundings. According to Mollino,

"To each architectural problem related to location and destination corresponds a solution that needs to result in architectural authenticity and, as such, automatically blends with the beauty of the landscape. New materials and new techniques can and must, as in the past, allow for the creation of mountain architecture as expression of an ideal consistency of the current world." ${ }^{\prime 14}$

Molino's words sum up Gellner's approach to the Village. Thus, materials and techniques of the prefabrication industry appear to be the main solution to express a modern architecture. The Triennale di Milano exhibition becomes "the testing ground for architecture and so-called industrial arts." 15 Above all, the $10^{\text {th }}$ Triennale di Milano ${ }^{16}$ provides Gellner with an array of various technological solutions, some of which he will employ in the Village, like the "Salvit" and "Novopan" panels ${ }^{17}$, the painting "Snowcem"18, and the Er-Cal system $^{19}$. While the employ of heavy prefabrication is soon eliminated from the building site ${ }^{20}$ because of land slopes, the architect employs prefabricated modular materials in an almost artisanal way by varying sizes, colours and finishing. The artisanal touch derives from Gellner's deep knowledge and experimentation of materials in his father's workshop in Abbazia, and as an interior designer ${ }^{21}$. Wood and stone of the Architettura anonima ampezzana ${ }^{22}$ are accompanied and mainly converted in 'artificial stone' - that is, concrete - by resorting to different formworks or superficial manufacturing during the removal phase - like incisions with a marteline - or by using prefabricated elements, in order to simulate the layering of the Dolomia stone dominating the surroundings. Thus, the whole village shows stone masonry or raw concrete structures in reinforced concrete left in its natural state, exposed secondary wooden and steel structures.

The possibility to develop a new language rested on the complete absence of other buildings in the area chosen for the construction of the village. Thus, nature becomes a protagonist of the development of this complex, instead of a mere physical limit against which to place the architecture. In particular, the two peaks of Pelmo and Antelao surrounding Borca represent the main instrument within the Colony to orient through the repetitive, monotonous, almost disorienting openings of ramps and buildings, and stand as veritable cardinal points. 


\section{THE COLONY}

\section{Genesis, development and architectural choices}

In the vast and complex system of the Villaggio Eni, the Colony stands as the main element in the Gellner and Mattei's reflections, as shown by their notes and letters: here, the Colony becomes the focus of the work in order to design it as an independent and self-sufficient organism within the Villaggio.

In its definitive conformation, the Colony appears to be composed of a series of isolated pavilions whose spaces host the different functions of the complex (acceptance and stay, refectory and dressing room, offices, services, infirmary, managers, religious and concierge lodgings, male, female and mixed dormitories) connected by covered ramps that wind on the slope of the mountain, ensuring the interconnection of all buildings as well as the overcoming of the difference in altitude. Gellner initially aimed to create a compact and monobloc system, where the entrance-living hall (AS) was surrounded by the other main buildings, then he developed those different buildings as autonomous units in order to avoid heavy earthworks that would have been necessary for the first project. The drawings show a progressive rotation of the system grid, which in this way seems to follow the mountain level curves. This definitive configuration was divided into a series of buildings with a longitudinal shape with, in the middle, the AS pavilion, marked out by a strong sloping roof that becomes a landmark within the composition, contrasting its horizontal trend. One of the main features of the layout was represented by a particular configuration of the pavilions' floors, designed as if they were independent; floors in the same building often didn't have vertical connections, and the same pavilion could host different functions at every floor. This design was made possible using ramps between or inside pavilions: these elements were placed on the facades, where they could

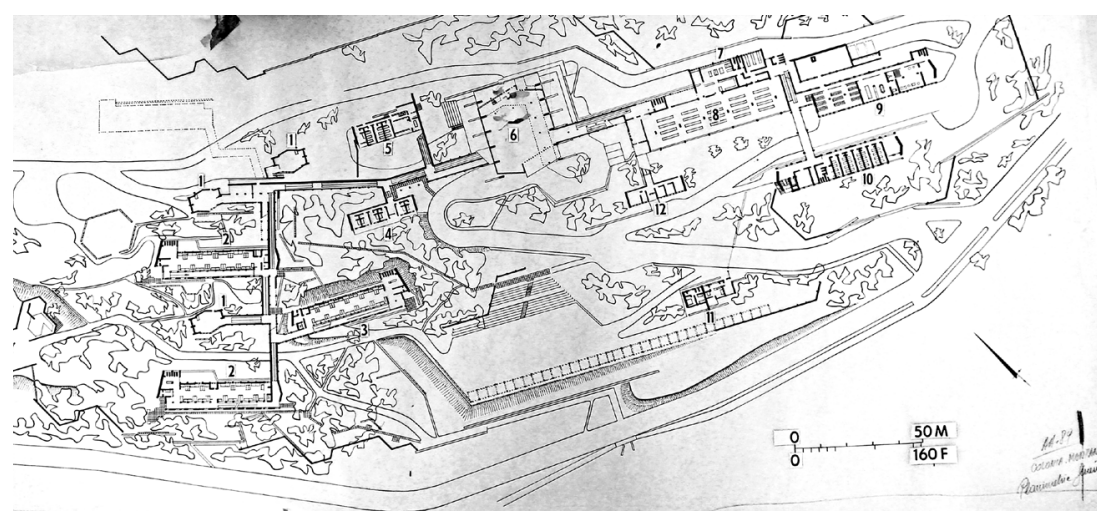

Figure 2. Colony plan (AP IUAV, Gellner, Vtab/Co, npr 58329) 
also shield the sunlight, or upstream of the buildings, and they drew the internal path as a fil rouge. A system of crossed ramps was also used by Gellner to avoid direct contact between males and females in the mixed dormitory.

A special attention was also given to the flexibility of social spaces, which were studied in such a way as to transform from a lecture hall to a game room: Gellner wanted to make children's lives as comfortable as possible, avoiding the "barracks system", that was so common in the childhood colonies of the time. He aimed to recreate a domestic environment, welcoming and comfortable, with which the children could quickly gain confidence, entrusting a fundamental role to the use of colours in the facades, in the furnishings and in the pipes of the showers. Gellner explained the key position covered by the different colours used in the Colony and the functions they perform. Attention towards the child is immediately denoted in the notes and sketches of the architect; the red note of the architect's hand "Measure: the child", placed at the bottom of the reports, therefore appears as a sort of reminder for a mandatory principle to obey in the design of the spaces.

Gellner devoted particular attention to the study of the facades, passing from a very monotonous composition, characterised by a grid of regular windows, to a second phase in which he tried to break this trend, adopting different types of openings combined with each other in order to give rhythm to the whole composition. As for the connections, the architect adopted the solution to place together square windows of different measures at variable heights, in order to maintain a perceptual bond with the exterior. Although the Colony is an "introverted" system, which develops all within, this solution allows the visitor to maintain a visual contact with the two "main heights" of the landscape: Pelmo and Antelao.

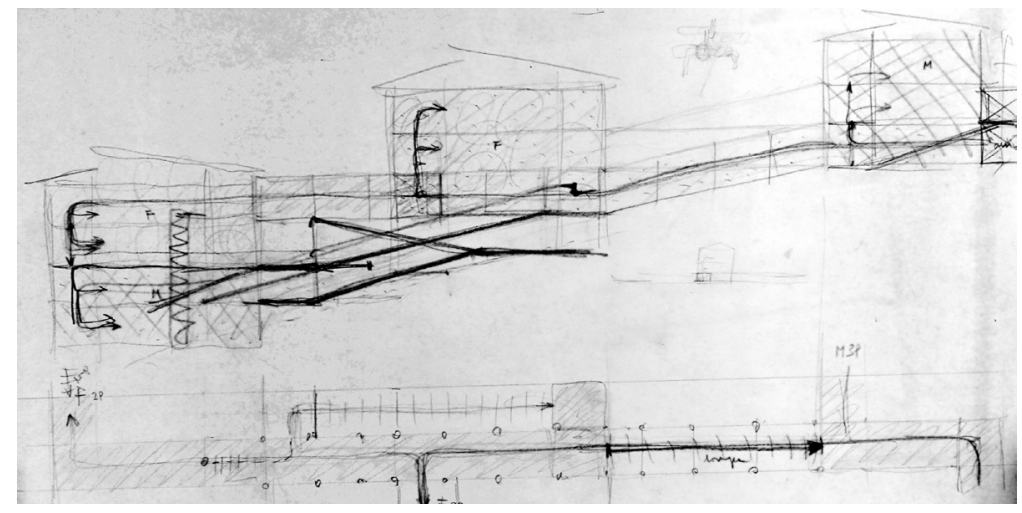

Figure 3. Sketch of the ramps (AP IUAV, Gellner, Vtab/Co, npr 58270) 


\section{Structural system, materials and construction techniques}

The Colony is a summary of technical and formal solutions, made possible thanks to a special client, and collaborations with contractors, with whom there is extensive exchange to better solve problems related to the works, and to the solution of particular elements of interior design ${ }^{23}$.

The structural and urban planning of the whole children camp is based on a modular orthogonal grid of $122 \mathrm{~cm}$ (multiple of the English foot), ${ }^{24}$ oriented East-West, following the topography of the land. A reinforced concrete cross frame is set up, on which orthogonal beams are inserted. This structure, used for all the buildings in the children camp except for the central building, makes clearly visible the element bearing the closing elements located in the center axis of the framework, such as aerated concrete panels or hollow clay bricks interposed to plastered Eraclit panels. On this structural frame, the architectural unity arises from the use of several materials, the surface treatments of concrete and stone, the multi-scale geometric modules, the primary colours dominating over neutral shades and the designing of child-proportioned furniture.

The great number of solutions adopted can be inferred from material and structural analysis of the main buildings, and from the architect's studies.

Many variations of the structural system exist for the Reception-Assembly building (AS), revolving around the idea of an imposing double-pitched structure reaching the ground, with gables closed by glass windows. The architect experiments on various structural forms, ${ }^{25}$ combining form and technique inferred from the several formal solutions for the V-shaped pillar,

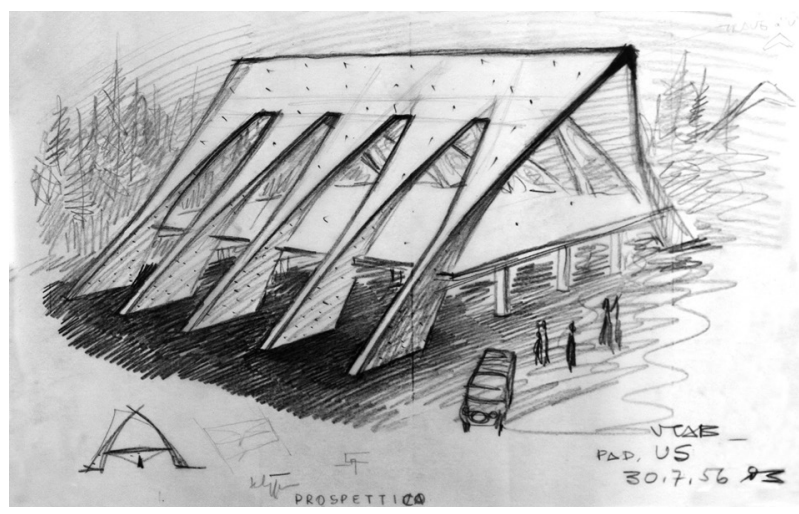

Figure 4. Sketch of the structure of the Reception-Assembly building "AS" (AP IUAV, Gellner, Vtab-CO/12, scatola 1/6) 
published and largely employed in the post-war period. In the adopted solution, the V-shaped pillar ${ }^{26}$ becomes an inclined compression member, formed by six reinforced concrete ribs spaced apart by $6,10 \mathrm{~m}$, which converge into a roof plate at the top. In the South façade, the solution includes steel-frame with windows and opaque panels of several shapes and sizes, showing the obsessive desire to eliminate repetitions.

Gellner calls upon the engineer Silvano Zorzi ${ }^{27}$ to calculate the building's structure, capable of combining aesthetics with technique, and shape with structure $^{28}$.The AS building's functioning is shown in the building site's pictures, in Gellner's technical report ${ }^{29}$, in Zorzi's structural drawing. The concrete rafters ${ }^{30}$ show variable sections: they are very stiff at the base, while they flatten and open themselves as a fan toward the vertex of the structure, thus forming portions of the roof's own pitch. These "trusses", as Gellner calls them, function as a triangular frame and they are calculated method of the ellipse of elasticity ${ }^{31}$, generally employed for the bridges design. They are embedded at the top and at the two supports, thanks to tie rods placed under the ground floor, which act as a pushing structure on the rafters. The structure is calculated according to two load diagrams: in case of symmetric load the intermediate floor acts as a tie beam and works together with the base floor; in case of asymmetric load the intermediate floor acts mainly as a strut. The intermediate floor is placed at less than one third of the overall height of the structure, which further stiffens the footing. The concrete rafters of the top floor are free to flex depending on the snow load, despite being embedded at the top. The building site was divided among each single span. For each concrete rafter, with a section going from $804 \mathrm{~cm}$ at the base to a mere $25 \mathrm{~cm}$ at the top, three main subsequent phases for the concrete casting were employed:
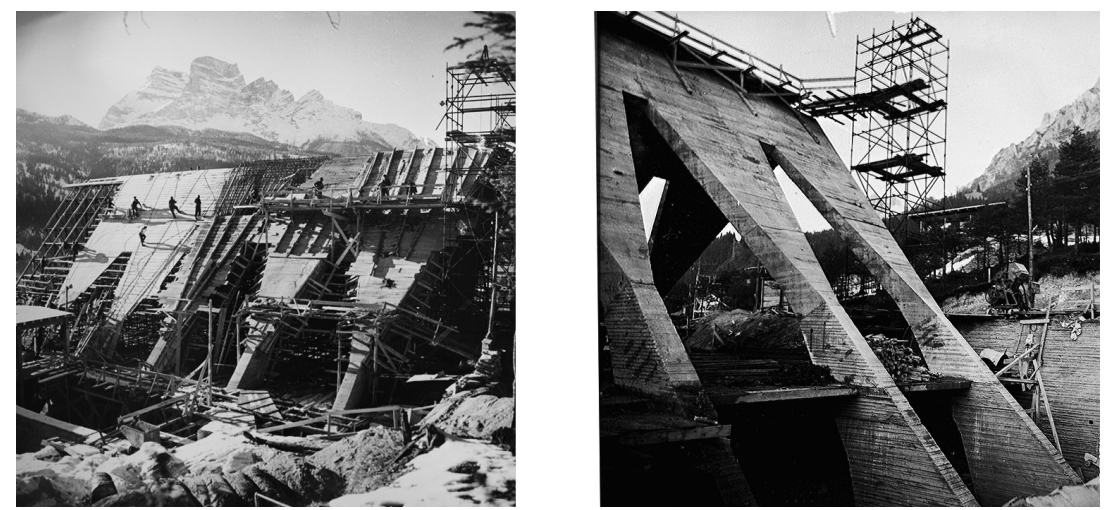

Figure 5. Building site's picture: concrete casting of the "AS" building (Left: AP IUAV, Gellner, Fotografie, Vtab-Co / enlarged picture of Fotografie, Co-Vtab campioni, 21-12-57 - GZ 1754; Right: AP IUAV, Gellner, Fotografie, Co-Vtab campioni, EG 1850) 
to each corresponds a change in tilting of the structure's intrados and specific surface treatments obtained through different formworks. The first section of the concrete rafters shows an embossed horizontal texture obtained through formworks composed of overlapping wooden planks of a different thickness. In the last section of the concrete rafters, a sharp line highlights the shift from a horizontally embossed surface to a smooth treatment of the concrete, whereas the interior of the pillar turning into pitch keeps the horizontal texture, but less pronounced compared to the base. This building doesn't showcase the cold roof like every other, whose ventilation space would have proved unnecessary due to the sharp slope of its pitches.

The large glazed North and South façades consist of a steel framework supporting wooden windows and having a wind bracing function. The steel columns are fastened to the floor and the concrete roof with sliding brackets to compensate the thermal expansion. The crosspieces are not hinged on the web of the beam but overlapped, as traditionally done with wooden structure. The Halls reprise on a smaller scale the same gable roof and materials of the central building $\mathrm{AS}^{32}$.

The Dormitories comprise dorm room on each floor arranged like a gallery, facing the ramps. This strategy allowed to sum the cubic footage of the ramps and the dorm rooms, reducing the height of the latter to 2,44 $\mathrm{m}$. Like the whole furnishing, the reduced height of the dorm rooms was designed with an eye toward the size and functional needs of children. The structure was built with a cross frame in reinforced concrete with stone masonry heads internally isolated by plastered Eraclit panels, cement mix floors and a double-pitched roof. The façades are closed to the South through aerated concrete prefabricated panels or
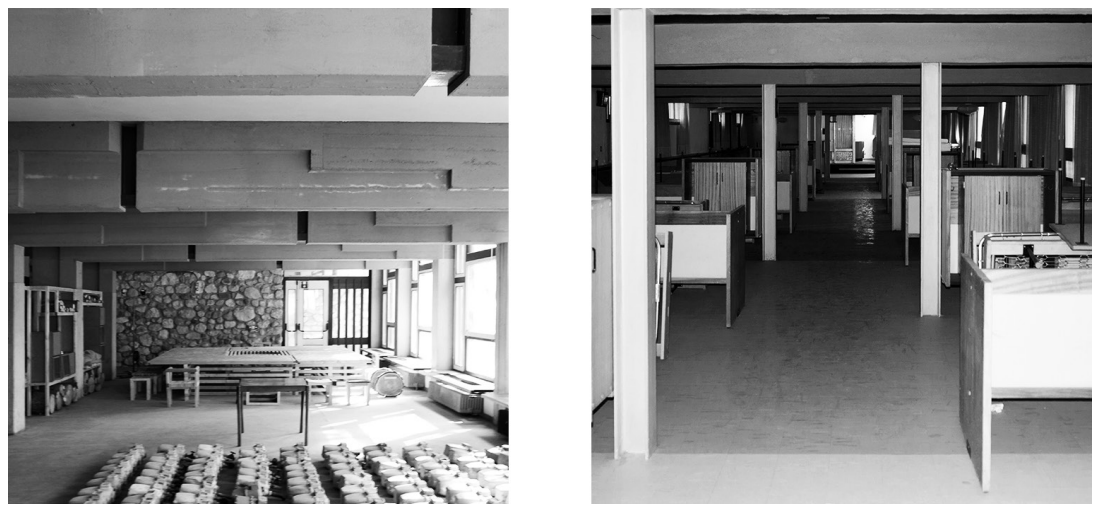

Figure 6. Left: Dorm room of the Dormitories buildings; Right: Living room at the ground floor of the Dormitories buildings 
insulated glass, and to the North through hollow clay bricks interposed to two plastered Eraclit panels ${ }^{33}$. The joint between the concrete frame and the aerated concrete panels is hidden by a prefabricated edge beam, allowing to distinguish the orthogonal load-bearing grid, and the curtain wall backward of the external thread of the façade. The apparently incidental alternation of full and glazed panels was studied to obtain homogeneous light in the interior.

The cold roof has pitches of staggered height at the top, obtained through their different slope. The thermal isolation - Eraclit panels, pumice and aerated concrete - is located on the horizontal floor of the top floor. This technological solution was tested for the two Caltex service stations ${ }^{34}$ where the traditional ampezzan roof ${ }^{35}$ - sharply sloped pitches usually covering the ampezzantoulàtype barn - is replaced by a roof with almost horizontal pitches so that the snow could not be discharged during the winter and contributed to the thermal insulating.

In the dormitories, yellow steel pillars divide the space of the central corridor and the arrangement of beds, located in boxes. Each box presents different colour combinations - yellow, light blue, grey - of the Novopan false ceiling panels and the prealino flooring ${ }^{36}$, helping the children to identify their beds.

On the ground floor, in the living room, the concrete load-bearing frame is paired to a portal frame, whose concrete beams look fragmented and offset, following the division by the intermediate elements of the upper levels. The surface of the beam decreases in three steps from its support on the pillar converging into the metal joint.
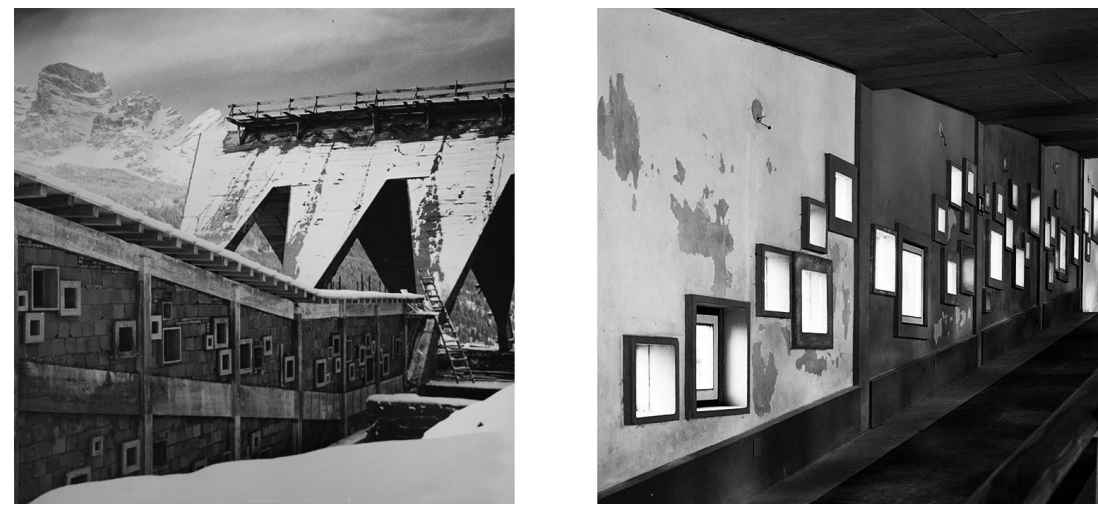

Figure 7. Left: Building site's picture: ramps (AP IUAV, Gellner, Fotografie, Vtab-Co, EG/1911) Right: The square windows of the ramps 
Beams and pillar

A different surface treatment differentiates the beams from the pillars: beams are made of unfinished concrete with a horizontal pattern left by the wooden formwork and pillars are made of smooth concrete painted grey. Gellner plays with the composition of glazed and opaque panels, and introduces a shape variation of beams prevailing on the mere structural function. The technique is moulded to create a unique distinctive shape of the architectural space. ${ }^{37}$

We find an analogous principle for the composition of shapes in the refectory on the second floor of the Refectory-Changing room building (RS). This functional separation exists in the building structures and in the different treatment of the material between areas destined to public (dining hall) and service (kitchen). In the dining hall, as opposed to the other rooms, Gellner uses wooden beams for the secondary frame of the roof abutted on cross frames in reinforced concrete, characterising the appearance of the hall. The building site pictures ${ }^{38}$ and the technical construction detail $\mathrm{s}^{39}$ show the constructive sequence of the various elements: the concrete beam tilted by 10 percent supports, perpendicularly, a wooden shelf composed of three chunks joined by steel connectors, decreasing in length towards the concrete beam. The wooden beam's central section is composed of three wooden chords decreasing towards the top to be inserted in the negative space between the two shelves. Assembled on the building site and joined by the same steel connectors, it is supported at the central line by a metal tie beam fastened to the secondary wooden framework ${ }^{40}$. However, in the kitchen, the concrete frame supports a secondary one in metal carpentry. Like in the dormitories, the two pitches covering the kitchen and the refectory have different slopes staggered in height at the top. In this case, the connection between the two pitches happens through a window screened by a larch grid $^{41}$.

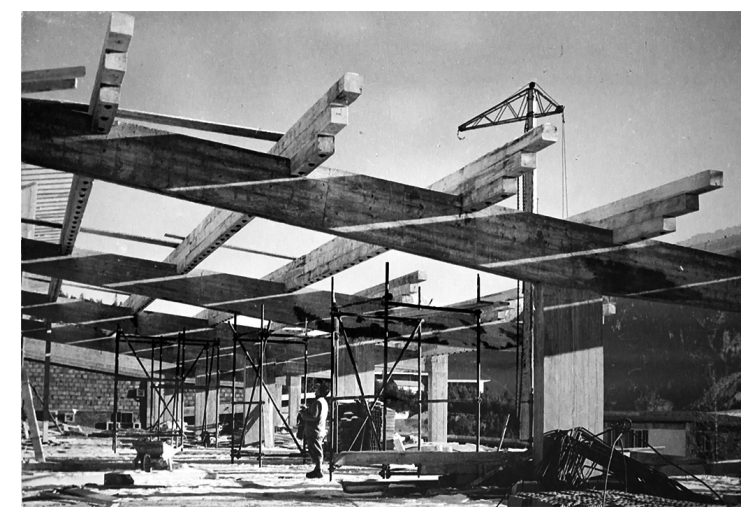

Figure 8 . Building site's picture: assembly of the wooden beams on the cross frames in reinforced concrete of the "RS" building (AP IUAV, Gellner, Fotografie, Vtab-Co / enlarged picture of Fotografie, Co-Vtab campioni, 21-12-57 - GZ/1756) 
The fake ceiling is built in aerated concrete panels in the kitchen and in Novopan yellow panels in the hall ${ }^{42}$; white versions of the latter are employed as coating for the side walls ${ }^{43}$. Another different material treatment for the marble prealino flooring in the refectory and the cold grey tiles in the kitchen, and the latter also displays a design of white mosaic tiles as wall finishing.

Finally, the Ramps merge and characterise the architectural composition of the Children camp, due to the variety of shapes, sizes and the bright colours alternating with white walls. Overall, the constant elements are the rubber flooring and the ceiling made of light blue panels which, however, does not hide the load-bearing structure. Each ramp's floor ${ }^{44}$ has striped black Pirelli rubber in the middle portion of the corridor, while on the edges a smooth rubber on a removal metal plate is in correspondence to the inspectional technical hollow for the systems. The ramps' distinctive features are the square windows in six different sizes composed of two prefabricated concrete elements: a rectangular section frame and a T-frame for fastening to the wall. The two elements are interchangeable between exterior and interior, and they house two glazed panels in different positions: in the junction point between the two prefabricated frames, toward the external or the internal edge. The glass can be transparent, coloured or textured with rhomboid pattern due to a steel mesh inside the panel, with or without a wooden frame. The infinite combinations of frames and glasses, accidental at first glance, are indicated in views and sections by a code for each type $^{45}$. These infinite possible combinations of elements create a unique play of compositions on the ramp's façades ${ }^{46}$. The square windows are reprised in the exterior in the game maze, consisting of prefabricated walls in concrete blocks.

Outdoor, too, the homogeneous use of materials creates the unity of these spaces: flooring made of square concrete pads or uneven porphyry stone slabs, boundary walls in stone masonry and in concrete blocks retaining walls in bulk concrete with horizontal patterned embossed. Especially, Gellner employs the retaining walls when he could not resort to ground movements and he considers them as an artwork $^{47}$, a special configuration to reduce the visual aggressiveness ${ }^{48}$, which is also achieved thanks to the appropriation by the surrounding nature. The greenery itself becomes part of the design: once found the most interesting element, it becomes decor for the exterior.

Gellner writes subsequently that raw concrete - marked more or less profoundly from the wooden formworks - played a role more and more decisive in the course of the works, and proved itself a very expressive element, able to establish a unique and eloquent formal counterpoint with the rock layers of the Antelao ${ }^{49}$. This unceasing experimentation earned Gellner the A.I.T.E.C and IN/ARCH 
prizes in 1962, for the demonstration of the possibilities within the employ of concrete with a sharp and expressive artistic and landscape sensitivity shown in the ENI Village at Corte di Cadore ${ }^{50}$. The use of only three materials, wood, steel and stone - both 'natural' and 'artificial'- allow Gellner to achieve uncountable technical and formal solutions making each corner of the Children camp unique, never become repetitive or plain as is the risk with modular, and partly prefabricated elements. Therefore, it is not only technological, but also spatial experimentation which guides the child in the different areas of the children camp, and becomes itself a game of forms and colours.

\section{CRITICAL RECEPTION}

The experience of Borca represented for Gellner the opportunity to confront again, after the projects for Cortina, with the subject, particularly dear to him, of architecture in mountain areas. In fact, it is at this time of starting this complex and vast project that it is possible to trace the first organic and systematic considerations on the modalities to be used to operate in places of particular landscape value, with the aim of creating a new language capable of being in harmony with the landscape and, at the same time, of embracing the most modern architectural features. Adopting this approach, Gellner seems to be willing to follow the instructions of Mario Cereghini - his companion in the Institute of Mountain Architecture - for which the architecture in the mountains had to refer to the landscape, and within it to camouflage and be in harmony ${ }^{51}$. To this topic Gellner dedicated, not surprisingly, his speeches at the 7th National Conference of Urban Planning, in 1959, presenting his experience as a designer of the Borca di Cadore complex ${ }^{52}$.

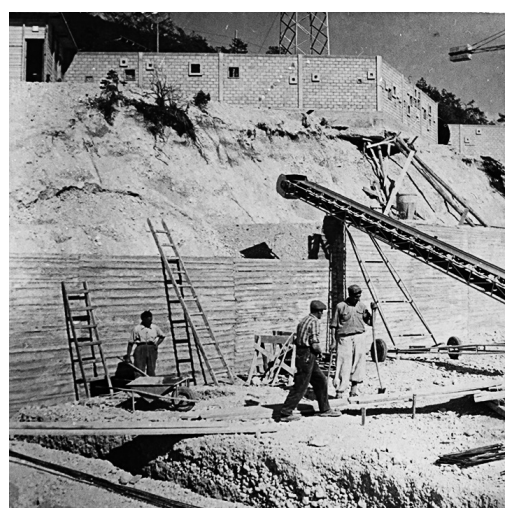

Figure 8. Building site's picture: concrete retaining walls (AP IUAV, Gellner, Fotografie, Co-Vtab campioni, 22-4-59 - EG/3551) 
The Eni Village thus ended up being the architect's "business card", becoming the manifesto of the Gellnerian vision of mountain design. It was Gellner himself who made vigorous efforts for the Village to be published in the most important architectural magazines, obtaining, in 1959, the attention of Bruno Zevi on L'architettura. Cronaca e storia. After some disagreements related to the diffusion of the projects of Cortina in other newspapers, Zevi had succeeded in obtaining the exclusivity on the publication of the Village from the architect, which only began to appear in other magazines in the Sixties ${ }^{53}$. A prolific partnership that led Zevi to write on the work of Gellner several times, even giving him the credit for having rehabilitated in his eyes the same actions carried out by Eni that he had severely criticised in his previous articles ${ }^{54}$.

The spreading of the knowledge of the village of Borca di Cadore gave Gellner a general appreciation from the community of architects and scholars, which fully understood its value not only from a functional or design point of view, but also as an exemplary case, in the light of its happy outcomes, to look at the relationship between the newly built complexes and the communities that live there. It is worth mentioning in particular the reflections of Giuseppe Samonà, who dedicated a review to Gellner's work in 1961, to be published in Casabella but remained unpublished ${ }^{55}$, in which the qualities and innovative elements of the project were highlighted, above all considering the internal organisation of the spaces.

Gellner's creation stood out for his profound features of discontinuity, favoured by the close relationship, woven by his architect, between the village and the surrounding landscape, until then substantially untouched, and where the Eni complex had constituted the first episode of anthropisation. Faced with this challenge, Gellner had shown "so much sensitivity to be able to express in a form that nicely emphasises the values of the landscape for those observing it from the outside, and to adapt this same landscape to measures and human relationships for those inside», realising effective architectures and paving the way for the good functioning of the community that would populate the village.

This favour with critics confirmed the profound relationship that had linked Gellner to the Borca di Cadore project, probably the most incisive and significant of his entire career. Also, for this reason, the architect continued to be interested in the events of the Village even after the conclusion of the first tranche of the works, coinciding with Mattei's commission; if in the Sixties, after the tragic death of its president, it was Eni itself charging Gellner to develop sports facilities and other interventions within Borca; also, in the following decade, when Eni had already started to progressively dismantle the 
site starting from the Colony, and disengaging from carrying of the functioning of the Village, Gellner went on privately developing solutions for the recovery and transformation of spaces. A "battle" for his Borca that Gellner kept up to the last years of his life, often seizing the opportunity to solicit the property and local institutions to take charge of the maintenance of the complex. about the Colony and Critical reception is studied by Alvise Trincanato; the Structural system, materials and construction techniques about the Village and, in particular about the Colony, is studied by Silvia Bezzecchi. The abbreviation AP IUAV is referred to the entire archive collection of Edoardo Gellner preserved in Archivio Progetti IUAV, Dorsoduro 2196 Cotonificioveneziano, archivioprogetti@info.it.

Special thanks to the entire team of the Archivio Progetti IUAV to give us a precious help for our research and for the possibility to publish some documents of the Edoardo Gellner found. An additional thank to Prof. Luka Skansi for his helpful advice for this research developed in the seminary of the $\mathrm{PhD}$ in History of Architecture and Urbanism at IUAV.

Archivio Progetti IUAV, Fondo Edoardo Gellner, Dossier 204, Nuove zone in trattative di acquisto (settembre 1956). nuovo schema urbanistico - Comuni di Borca e di Vodo (planimetria 1:2000 dd 15.12.'56). 
AP IUAV, Scatola 32, Dis Ur/1.

It is probably the area initially chosen by the Agip for the location of the Village, however there are no annotations or references that could confirm this hypothesis.

AP IUAV, Scatola 32, Dis Ur/3.

AP IUAV, Scatola 34, Dis Ur/9.

AP IUAV, Dossier 209, Disegni allegati alla domanda di nullaosta inoltrata dall'A.g.i.p. Mineraria al Comune di Borca di Cadore per la costruzione di una COLONIA MONTANA.

AP IUAV, Scatola 34, Dis Ur/22.

In this regard, it is interesting the relationship in which Gellner says he has studied the Cadorino social system, wanting in some way to want to re-propose it in modern terms within Borca. AP IUAV, Dossier 201, Appuntisparsi di relazioni.

The reference was to the most modern American shopping centers, in which real commercial streets were recreated. Here we find an element on the cultural references of Gellner, which through the magazines still held at the Angelini Foundation kept up-to-date on the architectural innovations of the rest of the world, not infrequently following the reading on site, as happened in the case of Scandinavian countries. In the specific case of the shopping centers, the origin of the suggestion can be found in the American «Architectural Record».

AP IUAV, Dossier 201, Opportunità di estendere i servizi del Centro.

Carlo Mollino, "Tabù e tradizione nella costruzione montana," Atti e Rassegna Tecnica della Società degli Ingegneri di Torino, no. 4 (1954): 151-154.

Ferdinando Aars. "Decima Triennale di Milano" (Milano: SAME, 1954), 15.

TheXTriennalediMilanoincludesasectiondedicatedtotheMostrainternazionaledellaprefabbricazione e dell'edilizia, with the demonstrative realization of several prefabricated houses, of which Gellner owns some catalogs. Gellner participates to that same Triennale with the Fantoni folding armchair.

Salvit is a panel with a base of asbestos-cement produced in size $122 \times 305 \mathrm{~cm}$, the same module employed by Gellner; the Novopan particleboard panel composed of wood particles bonded with special thermosetting synthetic resin. Both panels showcased at the X Triennale di Milano: the Salvit panel employed in the prefabricate mountain house named Holyday Sculponia (Arch. Luciano Baldessari, arch. Marcello Grisotti); the Novopan panel employed as false ceiling in the prefabricated Mountain House-shelter. AP IUAV, Dossier 201, lettera di corrispondenza; AP IUAV, Dossier 207, prefabbricazione. Ferdinando Aars. "Decima Triennale di Milano" (Milano: SAME, 1954).442-445 (Salvit panel) and 471-475 (Novopan panel).

Snow-cem is a colored cement used by Gellner in grey, especially in his concrete masonry as a finishing; showcased in the prefabricated mountain house named Holiday Sculponia at the X Triennale di Milano. AP IUAV, Dossier 201, lettera corrispondenza; AP IUAV Dossier 207, Prefabbricazione. Ferdinando Aars. "Decima Triennale di Milano" (Milano: SAME, 1954), 442445.

Er-Cal is a prefabricated building system where Eraclit panels form the formwork for concrete casting employed for residential areas; showcased at the X Triennale di Milano in the Industrial Country House (Arch. Luciano Baldessari, arch. Marcello Grisotti). AP IUAV,Dossier 207, Prefabbricazione. Ferdinando Aars. "Decima Triennale di Milano" (Milano: SAME, 1954), 446448; "Eraclit” n. 60, Ed. Venier S.p.a., Venezia.

The prefabrication studied for the first experimental houses, for which engineer Zorzi had suggested a precast prestressed concrete frame was not realized (AP IUAV, Gellner, Dossier 207, prefabbricazione).

The first of Gellner's works are published in: Bruno Zevi, "Un architetto colto: Edoardo Gellner", Metron, n. 39, (1950); Lisa Ronchi, "Cinque edifici nel centro di Cortina d'Ampezzo - Il Villaggio ENI, Corte di Cadore, (palazzo della Telve e delle Poste, casa Giavi, condominio "Residence Palace" e Motel AGIP)", L'architettura - Cronache e storia. n.44, (1954). 
E. Gellner publishes two books on traditional architecture of the Ampezzan valley: Edoardo Gellner, Architettura anonima ampezzana nel paesaggio storico di Cortina d'Ampezzo (Padova: F. Muzio, 1981); Edoardo Gellner, Architettura rurale nelle dolomiti venete (Cortina d'Ampezzo: Dolomiti, 1988).

Extensive correspondence with Agip in Rome and its Agip seat for the drafting of the executive drawings, which were executed by Agip itself on the basis of Gellner's project. The documents reveal promptness from Agip in requesting the definitive drawings to proceed with the works. AP IUAV, Dossier 201.

The same module employed by the English prefabrication industry is used as the unit of measurement in Italy.

Pogacnick Marco, "L'estetica dell'impersonale”, La concezione strutturale. Ingegneria e architettura in Italia negli anni Cinquanta e Sessanta (Torino: Allemandi, 2013)where the author sums up the structural forms and several uses of the V-shaped pillar addressed in Curt Siegel, Struttura e forma nell'architettura moderna. Translated by Giorgio Andreon (Bologna: CELI, 1968) $7 / 71-185$

AP IUAV, VTAB-Co/12, scatola 1/6: many sketches with different solutions of the structure.

The engineer S. Zorzi had his formation at theÉcolePolytèchnique of Lausanne avec professor G. Colonnetti, and after his degree in engineering at the University of Padua worked at the CNR of Turin, studying prestressed concrete.

The current bibliography about SilvanoZorzi lacks references to his assignment in the Eni Village at Borca di Cadore. References are made to his relationship with architects such as Mario Chessa, Eduardo VittoriaFigini e Pollini, Gregotti but not Gellner. Silvano Zorzi, Silvano Zorzi: ponti e viadotti. Museo di Castelvecchio, Verona, gennaio-febbraio 1981(Roma: De Luca, 1981); Angelo Villa and Ermes Martinelli, Silvano Zorzi: ingegnere 1950-1990. (Milano: Electa, 1995); Stefania Casucci and Stefania Lincetto, Silvano Zorzi e i suoi ponti. (Padova: Collegio degli ingegneri della provincia di Padova, 1995).

AP IUAV, Dossier 201, Relazione Parte Seconda, Criteri Urbanistici e Zonizzazione, Il Progetto, Cortina, dicembre 1958 agg. Dic. 59. The same technical report is partially reviewed and published in Valeria Fois, and Michele Merlo. Percepireilpaesaggio. (Milano: Skira, 2004).

The castings were made with concrete with a dose of $350 \mathrm{~kg}$ of high-strength cement and the reinforcement was made of special ribbed steel (type 680).

The calculation through ellipse of elasticity is based on the division of the element in a certain number of sections, thus studying for each of them the stresses in action against their center of gravity. In this case Zorzi divided each element's structure in ten sections.

Three frames in reinforced concrete with a triangular structure and a section decreasing towards the top create the framework for the roof in wooden purlins. The inside of the wooden framework is coated in a matchboarding of a mixture of spruce and larch wood. The gable's two glass panels are connected to the framework by a laminated beam on which a vertical wooden element fits with a mortice and tenon joint fastened to the top of the intrados of the concrete structure.

In the tables, an acronym indicates the indication of the wall's stratigraphic composition. In this case, L12-E3+3 indicates $12 \mathrm{~cm}$ hollow clay bricks interposed to two layers of Eraclit heat insulator, $3 \mathrm{~cm}$ each. The whole ensemble is coated with a $1 \mathrm{~cm}$ finishing layer of plaster both externally and internally.

The two Caltex service stations (1954, Cortina d'Ampezzo - La Riva) were designed by Gellner in collaboration with Luigi de Bonetti (in (curated by) D. Battistella and N. Pinton) Se vuole le raccontounepisodio ...posso? Intervistesu Edoardo Gellner, IstitutoBelluneseRicerche, 2009, p. 49). 
Prealino produced by Società del Linoleum; AP IUAV, Dossier 204, corrispondenza.

Wallspan grey paint; AP IUAV, Dossier 204, corrispondenza.

AP IUAV, Gellner 4. Professione/2/35,-38-39-46-7.

AP IUAV, Gellner, VTAB-Co/03.

The drawings kept in the Project Archive IUAV do not show the three partitions of the wooden planks, therefore, they were most likely subsequently developed or deriving from needs arisen during the works. As Luigi Bonetti, his collaborator, remembers the design happened live. Often, a detail was made [...] then taken to the building site, giving instructions live! [...] This was one of the characteristics of the village's creation. Quote from Daniel Battistella, and Nic Pinton. Interviste su Edoardo Gellner: se vuole le racconto un episodio...posso? (Belluno: IBRSC, 2009), 52.

The itemized list of the RS building describes the panels: larch grid for the whole length of the living room and the executive dining room. Load-bearing structure in triangular larch frames, bound to the wall through flat steel clamps. Grid elements in larch, included fluorescent tube lamp sockets and metal flower pots; included Perspex screen. AP IUAV, VTAB-Co/03/196.

The itemized list of the RS building describes the panels: Novopan structure, formed by Novopan panels, width 91,5 e 122 with mahogany edge roof secured to fake ceiling of thin spruce rods through wooden screws and washer. AP IUAV, VTAB-Co/03/196

The itemized list of the RS building describes the panels: wall coated in Novopan on both faces, with embedded the sliding doors' end-of-stroke locking system-including foam rubber cords plastic-coated. AP IUAV, Gellner VTAB-Co/03/196.

AP IUAV, Gellner VTAB-Co/01/028.

See for example AP IUAV, Gellner, VTAB-Co/01/056

See for example AP IUAV, Gellner VTAB-Co/03/071.

AP IUAV, Dossier 201, Relazione Parte Seconda, Criteri Urbanistici e Zonizzazione, Il Progetto, Cortina, dicembre 1958 agg. Dic. 59. The same technical report is partially reviewed and published in Valeria Fois, and Michele Merlo. Percepireilpaesaggio. (Milano: Skira, 2004).

"[...] The walls had to be straight and oriented on the base of multiples of fifteen degrees with respects to North (rule valid for every village building); slope of the façades $20 \%$; horizontal capstones, even for brief stretches; (straight) base detached from the (curve) road curb with an interposed grassy slope. Moreover, they had to be implemented with coarse concrete conglomerate and armed with live edge planks. Therefore, the walls appeared to have a coarse surface marked with irregular albeit horizontal grooves. In time, they covered with lichen, housing moss and even flowers and polar willow. Through such targeted building arrangements, many of these walls disappeared, blending in with rocks and greenery.” M. Merlo, Edoardo Gellner, Quasi undiario. Appunti autobiografici di un architetto, Gangemi Editore, Roma, 2008 p.134 (

Edoardo Gellner, "Dal Monte Maggiore all'Antelao - Esperienze del costruire in montagna negli appunti autobiografici di un architetto (cronistoria di Corte di Cadore)" (Liburnia: Rivista del CAI, sezione di Fiume, 1972), 12.

"Premio Nazionale A.I.T.E.C. 1962. Il Villaggio sociale Eni a corte di Cadore", L'industria italiana del cemento. n. 1,1963

Mario Cereghini. Costruire in montagna. Architettura e storia (Milano: Edizioni Del Milione, 1950).

Edoardo Gellner, “Corte di Cadore il villaggio sociale dell’ENI.” Urbanistica n. 32 (1960).

AP IUAV, Ricerche, Corrispondenza per pubblicazioni.

Bruno Zevi, “Un nuovo villaggio è nato in Cadore.” L'Espresso n. 35, (1958).

AP IUAV - Archivio Progetti, Fondo Samonà, FAS/079/23, G. SAMONÀ, Relazione critica sul villaggio di Borca di Cadore dell'arc. Gellner, unpublished. 
Aars, Ferdinando. Decima Triennale di Milano. Milano: SAME, 1954.

Achleitner, F., Paolo Biadene, Edoardo. Gellner, and Michele Merlo. Edoardo Gellner, Corte di Cadore. Milano: Skira. 2002.

Balducci, Valter, Architetture per le colonie di vacanza: esperienze europee. Firenze: Alinea, 2005.

Battistella, Daniel, and Nic Pinton. Interviste su Edoardo Gellner: se vuole le racconto un episodio...posso?. Belluno: IBRSC, 2009.

Bolzoni, Luciano. Architettura moderna nelle Alpi italiane dal 1900 alla fine degli anni Cinquanta. Ivrea: Priuli\&Verlucca, 2000.

Bolzoni, Luciano. Architettura moderna nelle Alpi italiane dagli anni Sessanta alla fine del XX secolo. Ivrea: Priuli \&Verlucca, 2001.

Bolzoni, Luciano. Abitare molto in alto: le Alpi e l'architettura, Scarmagno: Priuli \& Verlucca, 2009.

Cannizzaro, Angelo. Edoardo Gellner: architetture organiche per Enrico Mattei, 1954-1961: atti della Giornata di studi Roma, Gela, Pieve di Cadore: sala Herzog, Facoltà di architettura, Roma Tre, 17 marzo 2005, Roma: Gangemi, 2006.

Carraro, Martina, and Riccardo Domenichini. Architettura, paesaggio, fotografia: studi sull'Archivio Edoardo Gellner. Padova: Il poligrafo, 2015.

Casucci, Stefania, and Stefania Lincetto, Silvano Zorzi e i suoi ponti. Padova: Collegio degli ingegneri della provincia di Padova, 1995.

Cereghini, Mario. Costruire in montagna. Architettura e storia, Milano: Edizioni Del Milione, 1950.

Cereghini, Mario. Introduzione alla architettura alpina: con 81 illustrazioni. Milano: Edizioni Del Milione, 1953.

Chiaia, Vittorio, Prefabbricazione - Case unifamiliari prefabbricate di tutto il mondo. Bari: Leonardo da Vinci, 1963.

Ciucci, Carlo. "Vacanze a Borca di Cadore (al villaggio montano dell'Eni)”. Il Gatto Selvatico. n.9, September 1957.

Desideri, Paolo. La concezione strutturale. Ingegneria e architettura in Italia negli anni Cinquanta e Sessanta. Torino: Allemandi, 2013.

Fois, Valeria, and Michele Merlo. Percepire il paesaggio. Milano: Skira, 2004.

Gellner, Edoardo. "L'architettura spontanea in tema di difesa e valorizzazione del paesaggio rurale", in Difesa e valorizzazione del paesaggio urbano e rurale. Atti del VI Convegno Nazionale di Urbanistica; Lucca, Teatro del Giglio, 9-11 novembre 1957, Roma: Istituto Nazionale di Urbanistica, 1958.

Gellner, Edoardo “Corte di Cadore: il villaggio sociale dell'ENI.”. Urbanistica, n. 32 (December 1960).

Gellner, Edoardo, "Dal Monte Maggiore all'Antelao - Esperienze del costruire in montagna negli appunti autobiografici di un architetto (cronistoria di Corte di Cadore)". Liburnia, Rivista del CAI, sezione di Fiume. 1972.

Gellner, Edoardo. Architettura anonima ampezzana nel paesaggio storico di Cortina d'Ampezzo. Padova: F. Muzio, 1981.

Gellner, Edoardo. Architettura rurale nelle dolomiti venete. Cortina d'Ampezzo: Dolomiti, 1988.

Gellner, Edoardo. Quasi un diario: appunti autobiografici di un architetto. Roma: Gangemi, 2006.

Gellner, Edoardo. Disegni di architettura e paesaggio. 2 voll. Roma: Gangemi, 2006. 
Guiccione, Margherita. "Paesaggio a misura d'uomo.” Finnegans. n. 16 (2009).

Mancuso, Franco. Edoardo Gellner: il mestiere dell'architetto. Milano: Electa, 1996.

Mancuso, Franco. "I cent'anni di Edoardo Gellner." Finnegans. n. 16 (2009).

Mollino, Carlo, and Franco Vadacchino. Architettura: arte e tecnica. Torino: Chiantore, 1948.

Mollino, Carlo. "Tabù e tradizione nella costruzione montana." Atti e Rassegna Tecnica della Società degli Ingegneri di Torino, n. 4 (April 1954).

Moretto, Luca. Architettura Alpina in Valle d'Aosta. Albini, BBPR, Cereghini, Figini e Pollini, Melis, Mollino, Muzio, Ponti, Sottsas sr., Sottsass jr. Quart: Musumeci, 2003.

Mucelli, Elena. Colonie di vacanza italiane degli anni '30: architetture per l'educazione del corpo e dello spirito. Firenze: Alinea, 2009.

Mucelli, Elena, and Claudia Cagneschi. Edoardo Gellner. similitudine distinzione identità, Atti della Giornata di Studi (Gambettola, 27 novembre 2010) e della mostra Edoardo Gellner@ Fabbrica. Bologna: CLUED, 2011.

Poretti, Sergio. Modernismi italiani: architettura e costruzione nel Novecento. Roma: Gangemi, 2008.

Ronchi, Lisa. "Cinque edifici nel centro di Cortina d'Ampezzo - Il Villaggio ENI, Corte di Cadore, (palazzo della Telve e delle Poste, casa Giavi, condominio "Residence Palace" e Motel AGIP)", L'architettura - Cronache e storia. n.44

Santi, Carlo. "Un villaggio per le vacanze a Corte di Cadore.” Comunità, n. 78 (1960).

Siegel, Curt. Struttura e forma nell'architettura moderna. Translated by Giorgio Andreon. Bologna: CELI, 1968.

Villa, Angelo and Ermes Martinelli, Silvano Zorzi: ingegnere 1950-1990. Milano: Electa, 1995.

Zevi, Bruno. "Un architetto colto: Edoardo Gellner.” Metron, n. 39 (1950).

Zevi, Bruno. “Un nuovo villaggio è nato in Cadore.” L'Espresso. n.35 (1958).

Zorzi, Silvano. Silvano Zorzi: ponti e viadotti. Museo di Castelvecchio, Verona, gennaio-febbraio 1981.Roma: De Luca, 1981.

"Holiday Village at Cortina, Italy (villaggio ENI di Corte di Cadore)." Architectural Design. n.6 (1960).

"Premio A.I.T.E.C., (possibilità d'impiego del cemento nel paesaggio naturale - villaggio ENI di Corte di Cadore", Ingegneri Architetti.

"Villaggio «Corte di Cadore» dell’ENI.” Eraclit. n.61.

“Premio Nazionale A.I.T.E.C. 1962. Il Villaggio sociale Eni a corte di Cadore”, L'industria italiana del cemento. n. 1, 1963.

"Eraclit". n. 60, Ed. Venier S.p.a., Venezia.

“I centri dell’ENI per le vacanze dei suoi lavoratori. Il villaggio di Corte di Cadore, le villette, gli alberghi, la colonia, il campeggio, la chiesa, Il Gatto Selvatico. Supplemento, 1962. 


\section{EDOARDO GELNER I SELO CORTE DI CADORE \\ Silvia Bezzecchi, Alvise Trincanato}

U ovom radu se razmatra selo Eni (Eni), smešteno u mestu Borca di Cadore, koje je projektovao Edoardo Gelner pedesetih godina dvadesetog veka kao jedan od najupečatljivijih primera planinske arhitekture, i kao jedinstvenu studiju slučaja istovremenog projektovanja objekata posebno naselja (kolonije) - i zajednice smeštene u njima, od master plana do detalja.

Dečji kamp se smatra rezimeom celokupnog rada ovog arhitekte. Mnoge ideje o upotrebi drveta, kamena - materijala koji pripadaju lokalnoj tradicionalnoj tehnici gradnje - betona livenog na licu mestu i prefabrikovanog betona su sprovedene u delo u dečjem kampu. Posebno su korišćene razne betonske oplate da bi se dobili razni oblici i teksture, a upotreba modularnog prefabrikovanog betona dovela je do velikog broja oblika i kombinacija. Ova rešenja su usmerena na uklapanje veštačkih elemenata u okruženje netaknute prirode.

Polazeći od ovih pretpostavki, cilj ovog rada je da analizira planiranje, tehničke i formalne odluke donete u dečjem kampu, a referišući na raspravu o upotrebi prefabrikaciji nakon Drugog svetskog rata - posebno u vezi izgradnje INA-CASA - i novog jezika alpske arhitekture.

KLJUČNE REČI: GELLNER, VILLAGIO ENI, PLANINSKA ARHITEKTURA, PREFABRIKOVAN BETON I BETON LIVEN NA LICU MESTU, ITALIJA

\section{IZGRADNJA I POUKE U FALKERI: INA-CASA STAMBENO NASELJE U TORINU ARHITEKTE DJOVANIJA ASTENGA} Giorgia Sala, Nicolas Moucheront

Falkera (Falchera) je socijalno stambeno naselje na periferiji Torina koje je projektovao Djovani Astengo (Giovanni Astengo) i grupa arhitekata pedestetih godina u okviru INA-Casa programa. Zamišljeno kao idealno organsko naselje, ono je predstavnik jedne težnje za životom u zajednici na periferiji urbane oblasti, razvijano u okviru pokreta Comunità (zajednica) koje je predvodio Adrijano Oliveti (Adriano Olivetti). Arhitektura je bila jedan od načina kojim se promovisao ideal života, a projektantski postupak koji su primenjivali Astengo i druge arhitekte na projektu Falkere morali su dodatno da obuhvate komunikacione strategije. Koncept organskog naselja razrađen je do samog arhitektonskog detalja upotrebom šestougaonog obrasca koji je stvorio mnoge poteškoće na gradilištu, o čemu svedoče arhivski dokumenti sačuvani u Veneciji i Torinu. Centar mesne zajednice (civic centre) je primer sveukupne složenosti projekta u samo jednom elementu, pečurkastom stubu primenjenom na oblikovanje glavnog trga. Uprkos poteškoćama u realizaciji i održavanju, ovo naselje ipak doprinosi identifikaciji stanovnika Falkere sa njihovim naseljem i okruženjem.

KLJUČNE REČI: SOCIJALNO STANOVANJE, ORGANSKA OKRUŽENJE, COMUNITA (ZAJEDNICA), ADRIJANO OLIVETI (ADRIANO OLIVETTI), ŠESTOUGAO, NEOREALIZAM, URBANO PLANIRANJE 